\title{
Visions of the Future of (Legal) Education
}

\author{
Michael J. Madison
}

March 21, 2014

University of Pittsburgh Innovation Practice Institute White Paper No. 2014-01

University of Pittsburgh Legal Studies Research Paper No. 2014-13

Available at:

http://dx.doi.org/10.2139/ssrn.2412238

\section{UNIVERSITY OF PITTSBURGH \\ I N N O V A T I O N \\ PRACTICE INSTITUTE \\ $S C H O C O L O C F$ L A W}

\section{PITT LAW}




\title{
Visions of the Future of (Legal) Education
}

\section{Michael J. Madison*}

\begin{abstract}
:
One law professor takes a stab at imagining an ideal law school of the future and describing how to get there. The Essay spells out a specific possible vision, taking into account changes to the demand for legal services and changes to the economics and composition of the legal profession. That thought experiment leads to a series of observations about values and vision in legal education in general and about what it might take to move any vision forward.
\end{abstract}

\footnotetext{
* Professor of Law, University of Pittsburgh School of Law. Email: michael.j.madison@gmail.com. This Essay grows out of a series of posts to madisonian.net, a blog, in November and December 2013. The ideas presented here should not be attributed to the University of Pittsburgh, the University of Pittsburgh School of Law, or to members of their respective faculties or administrations. I owe debts to Deven Desai, Frank Pasquale, Daniel Rodriguez, William Henderson, Bernard Burk, David Thompson, the team at IAALS (the Institute for the Advancement of American Legal Education), and my fellow IAALS Fellows for numerous stimulating and enlightening conversations about legal education. Comments of all sorts are welcome.
} 


\section{Madison, Visions of the Future of (Legal) Education \\ Page 2 of 38 \\ March 20, 2014}

\section{Introduction}

What should legal education become?

Law professors and others have been debating this question for years, even decades, with the question becoming more pointed in the post-2008 recession. Much of the debate has focused on how to frame the question rather than on answering the question itself. "Framing" topics include: How much should law students' growing debt loads matter? Is there a meaningful risk that relaxing accreditation standards will return us to a hierarchy of law schools running from the elites on one end of the spectrum to so-called trade schools, on the other end? Does that risk matter? Do we care about producing new lawyers who help underserved (and un-served) populations? Should we prioritize employability? What about justice? Etc. etc. These are all important questions, but they are the kind of questions that law professors are good at asking and answering. ${ }^{1}$ They are not guides or plans for action.

My goal here is to start with something different, something that most law professors do not spend much time putting to paper, even if it is something that they sometimes imagine that they might create: A mostly fleshed-out vision of what a law school of the future might look like. I am interested, in short, in what my law school of the future would look like, if I had the power to make it so. After setting out the vision and some extensions and modifications, I explain and justify it in part. In conventional legal scholarship terms, that sequence is backwards; conventionally, I should take a long run at explaining the problem, explaining my method for solving the problem, and then offer the proposal. But "backwards" is part of the point. In a

1 I have engaged in my share of this. See, e.g., Law Schools and Law Firms, madisonian.net, http://madisonian.net/2008/04/07/law-schools-and-law-firms/ (Apr. 7, 2008); Legal Education Questions, madisonian.net, http://madisonian.net/2008/04/08/legal-education-questions/ (Apr. 8, 2008); Too Many Law Schools?, madisonian.net, http://madisonian.net/2008/04/08/too-many-lawschools/ (Apr. 8, 2008); Gender and Race in Legal Education, madisonian.net, http://madisonian.net/2008/04/10/gender-and-race-in-legal-education/ (Apr. 10, 2008); Crunch Time, madisonian.net, http://madisonian.net/2008/04/11/crunch-time/ (Apr. 11, 2008). Those posts were part of a multi-author "mobblog" on the future of legal education at madisonian.net, organized by Professor Deven Desai of Thomas Jefferson Law School to coincide with the launch of a new law school at the University of California Irvine. See also Mike Madison's Advice for Erwin Chemerinsky: Require Students to Have Two Years of Experience Before Enrolling, TaxProf Blog, http://taxprof.typepad.com/taxprof_blog/2007/09/mike-madisons-a.html (Sept. 30, 2007). 


\section{Madison, Visions of the Future of (Legal) Education \\ Page 3 of 38 \\ March 20, 2014}

modest way, I want to start anew. It's a "what if?” exercise. I don't really think that I can build a brand new law school or model law school. I don't really want to. (Well, maybe so. It might be fun.) The point, of course, is to use a blue sky exercise such as this to see bits and pieces of what is realizable and where our collective imaginations currently get in the way of change. What can we learn by trying to begin again?

Along the way, it will become clear that much of what I have to say derives from and therefore applies to institutional change beyond the world of law schools. Legal education may or may not be in crisis at the moment, but economic and cultural pressures on law schools are acute. And those pressures are not isolated to law schools. They're connected to economic and cultural pressures on the legal profession, and to economic and cultural pressures on higher education more broadly.

Because I share the view that law schools are facing some critical challenges right now, I am not going to defend the need for novelty. People who are mostly satisfied with the current state of legal education are not likely to be persuaded by a case that points in a new direction. I am not going to rely on data about jobs or income for new graduates or law student debt. That material is pretty well-known; there is no point in my rehashing it. The same is true of the findings of the MacCrate Report and the Carnegie Report and the work of lots of other thoughtful people. A lot of it is useful, but I don't build specifically on any of it.

I have been reading, thinking, and occasionally writing about legal education and the legal profession for several years. I've been an occasional candidate for law school deanships, the chair of a task force at my law school charged recently with studying "innovation" in the law school program, and an occasional on-line kibitzer on legal education. ${ }^{2}$ Dean candidates are usually tasked to assemble a "vision

2 See, e.g., Legal Education and the End of the Beginning, The Faculty Lounge, http://www.thefacultylounge.org/2012/10/legal-education-and-the-end-of-the-beginning.html (Oct. $25,2012)$. Anyone who writes anything on the subject of contemporary legal education is subject to criticism for not appropriately prioritizing others' primary concerns, particularly the cost to attend law school and the money borrowed to pay it. For reasons explained in the text, I don't discount those concerns but don't treat them as absolutely foundational. And to show that I have written about those concerns elsewhere and at length, read not only the comments to the blog post cited above but also What Ails Lanyers and Law Schools, Pittsburgh Edition, Pittsblog, http:/ / pittsblog.blogspot.com/2011/01/what-ails-lawyers-and-law-schools.html (Jan. 4, 2011). 


\section{Madison, Visions of the Future of (Legal) Education \\ Page 4 of 38 \\ March 20, 2014}

statement" as part of their candidacy. What follows first is not so much the vision statement that I would actually give as part of an application for a deanship, but rather the vision that I would use if I had the resources to start my own law school from scratch. ${ }^{3}$ If I were to remove a variety of real-world limitations, such as compliance with accreditation requirements, the need to get changes approved by faculty colleagues, and the cost of putting things in place, what could, would, and should my new law school look like?

\section{Version 1.0: The Vision}

What follows is Version 1.0 of a personal vision. Idiosyncrasy means, among other things, that I have undoubtedly missed elements that others find compelling, recharacterized and possibly mischaracterized things suggested elsewhere, and even, in the view of some, added in extraneous and unnecessary stuff. At least some of what follows owes its inspiration to colleagues near and far, both in space and in some cases in time. I won't cite to them or otherwise annotate this sketch, even though the provenance of many of these ideas will be reasonably clear to many. ${ }^{4}$ It is my own thing.

This is almost entirely infeasible as an actual working model of a real law school. It is an idealization of what I would build and what I would do if I had all the time and the resources in the world. Give me \$200 million (substantially less than all the resources in the world, but still a lot of money), and as the late Jackie Gleason once said, away we go.

\section{A. Beginnings}

Here are my premises.

\footnotetext{
3 In response to the immediate challenge that the world does not need another law school, I plead agreement. The world does not need another law school that more or less resembles most of the world's current law schools. The world may need, or find useful, something entirely different.

${ }^{4}$ Portions of what follows owe their origins to writing by Samuel Estreicher and Daniel Rodriguez, to programming at the School of Management at Yale University and to Yale's undergraduate Directed Studies program, and to scholarly contributions by John Henry "Jack" Schlegel.
} 


\section{Madison, Visions of the Future of (Legal) Education \\ Page 5 of 38 \\ March 20, 2014}

The idea of law school still makes sense. That is, there is a discipline called "law" that can and should be both taught and studied in a post-graduate, universitybased institution.

A law school program should be grounded in the body of knowledge that defines the discipline and in corresponding disciplinary habits or faculties of mind. Practices and the ethos of the discipline are important, too; knowledge, practice, and ethos are three interwoven parts of a single fabric. Call them "knowing," "doing," and "being." No one of them should be prioritized over the other two, in educational terms.

A law school should be guided by a sense of what the products of law school should be.

Scholarship is one essential product. I list it first so that it's not forgotten in a discussion of academic programming for students. It is certainly possible to organize a law school that does not identify scholarship as a key product, but in my view such a law school does not belong in a university, or, if the school is standing alone, such a law school has no claim to being an academic institution. Law was one of the handful of disciplines that has been taught continuously in universities since those institutions were invented more than 800 years ago. I see no good reason to abandon that tradition and lots of good reasons, including reasons that relate to the broad and effective education of new members of the profession, to continue it. ${ }^{5}$

"Graduates" are essential products, but it is important to differentiate them. The proportion of law school graduates who start careers as practicing lawyers has been falling and, in my view, will continue to fall. A law school should be preparing students not only for service as practicing lawyers but also for careers in adjacent fields, including business, government, and not-for-profit service. And a law school should be preparing students to direct their own careers as much as possible, rather than respond to the winds of change that blow through employment markets.

${ }^{5}$ For more thoughts on this, see Michael J. Madison, The Lawyer as Legal Scholar, 65 U. Pitt. L. Rev. 63 (2003) (reviewing Eugene Volokh, Academic Legal Writing). 


\section{Madison, Visions of the Future of (Legal) Education \\ Page 6 of 38 \\ March 20, 2014}

Putting the same case somewhat differently, the communities and people that a law school's graduates serve are a law school's products of sort, both indirectly and directly. Law and law practice are about impacting the lives of those around us on both "micro" and "macro" scales. Recognizing changing employment markets for new graduates means recognizing changes in the demand for what have been called law practice and "legal services." People (and firms, and governments) still need legal services and likely always will, but increasingly they do not need lawyers to provide them, at least not in the numbers that they once did and/or not at the prices that they were once willing or able to pay. That's true both at the individual client / consumer / small law office end of the spectrum and at the large institutional client / Big Law end of the spectrum. Any particular law school could focus on supplying the market for lawyers (which, increasingly, is flat), or on supplying the market for legal services (which, increasingly, is growing, if not booming), or on supplying some combination of the two, with full recognition of the changing institutional character of both as well as the impact of those changes on individuals. I think that some combination is the best approach, partly because the nature of the demand for legal services is apt to (continue to) change, and partly because a school that commits too heavily and inflexibly to one model or another runs a risk of missing the market entirely, if not now then sometime down the road. I would not plan for a law school to produce "lawyers" in any traditional sense; I would plan for a law school to produce graduates who might practice law but more importantly who would embody the values, skills, and sensibilities of a modern lawyer in any and all professional domains where they work and serve.

Market metaphors fail to grasp some essential elements of law, law practice, the legal profession, law schools, and their places in broader communities. Law and lawyers embody and are embodied in sets of shared values and ideals as well as sets of institutions and practices. In meaningful respects all law schools should be accountable for ensuring that those things are taught and learned effectively. But we prioritize conversations about values and ideals at the risk of ignoring the brute facts of markets and money and the opportunities as well as the risks that those create. We tend to talk about these things in distinct narratives, but they overlap, and there is no good reason to keep them separate. Any vision of legal education has to respect both of them. Legal education should both emphasize the specific value of studying law but also embrace its inherently interdisciplinary and heterogeneous character. Legal education should borrow effectively from management education, information science 


\section{Madison, Visions of the Future of (Legal) Education \\ Page 7 of 38 \\ March 20, 2014}

education, and liberal arts education, among other fields. It should not be afraid both to undertake dramatic renovation and to experiment with new strategies that may or may not succeed. In part this represents service to our students and to the communities where they live and work. In part it also represents competitive necessity. A law school cannot justify itself competitively on the ground that law is in any respect "special" or otherwise immune from broader market trends. A law school cannot participate effectively in the world without recognizing how changeable that world is.

\section{B. Elements}

Turning from premises to the elements of the school:

The quality of a law school's program depends in large part on its underlying human capital - its students and its faculty. Before going into curriculum, programs, and courses, I briefly describe who (and what) I think belongs at the school.

Students:

The total number of students per entering class should be no more than 100 . That's an arbitrary number; it could be 120 or it could be 80 . The point is that the class should be small enough that every student can be acquainted with every other student. The smaller cohort also keys into aspects of the teaching program (below) that concern course size.

No student should be admitted to the school until that student has completed at least two years of non-academic post-collegiate activity of some sort. Graduate school or other professional education would not count; any kind of sustained work or volunteer experience would count. Two years is arbitrary; it could be longer. The point is that anecdotal observation strongly suggests that students with some life experience make better students, make better lawyers, and do extremely well in the job market. Some higher quality data from law schools that have moved toward this model (notably Northwestern) suggest that it has some empirical foundation. Also, no student would be admitted without completing an interview conducted by at least two 


\section{Madison, Visions of the Future of (Legal) Education \\ Page 8 of 38 \\ March 20, 2014}

faculty members (this borrows from medical education). I would apply this requirement even with respect to students who aspire to careers in scholarship. ${ }^{6}$

With that minimum, who would be admitted to the school, and how? I would look to admit a body of students as well as individual students, meaning that the blend and balance of individuals represented would be as important as individual achievement and ambition. "Objective" criteria (grades, board scores) are highly imperfect measures; I would admit students partly based on academic and nonacademic records and partly based on extensive in-person interviews. (That's more work for the faculty, I know.) I can't know in advance who the market for this sort of institution would be. Admissions goals and strategies would have to be at least somewhat flexible.

Faculty:

For a student body of such a small size, I would picture a full-time faculty of roughly 25-30 members. More, perhaps, and maybe a lot more, once all the functions of faculty members that I describe below are factored in. The raw number is less important than what faculty members would do and would be capable of doing. Every faculty member should be prepared to and willing to conduct substantive scholarship and to teach in any aspect of the curriculum. There would be no dedicated faculty corps for legal writing or clinical education or for any other dimension of the program devoted in principal part to "skills" or "competencies." I would not necessarily put a premium on faculty members who have practiced law or worked professionally; in some cases that kind of experience can be deadening both in the classroom and in scholarship. (The inverse should be true as well: There is no reason to avoid appointing faculty who have practiced for more than a trivial amount of time.) I would not necessarily put a premium on faculty members with formal interdisciplinary or multidisciplinary training (JD/PhD, JD/MD, JD/MBA).) I would put a premium on faculty members who are genuinely and thoroughly committed to integrating the practice of scholarship and teaching, and who in their teaching are genuinely and thoroughly committed to the whole preparation of each student, through substantive knowledge, practice, and ethos, for careers in the legal profession.

${ }^{6}$ In earlier writing I suggested that students might be given the option of applying without disclosing an LSAT or other standardized test score. See Gender and Race in Legal Education, supra note 1. I continue to think that this would be a good idea. 


\section{Madison, Visions of the Future of (Legal) Education \\ Page 9 of 38 \\ March 20, 2014}

Budgets, Expenses, Funding:

This group of teacher/scholars would represent a rare breed. If they could be found these people would likely command a premium in terms of compensation. So would professional staff needed to support them, partner with them, and to fully bring this vision of a law school to fruition. My vision is very explicitly a "money is no object" vision. What would tuition be? Would tuition even be necessary? If I were to price this out, I would want to cap total student costs per year at $\$ 20,000$ or less. That's an arbitrary number; it could be a little more or a lot less. Yale's School of Music received an endowment that permits the School to offer graduate degrees to every admitted student for free. Making my vision of law school work would require a substantial endowment - likely well over $\$ 150 \mathrm{~mm}$, I think, because there is no way that student fees would pay for it. And if there is that much money available, then there may be little reason to make students pay anything.

The program itself:

Length:

I would grant the JD degree after two years but not permit students to sit for a bar exam until the end of year 3 or even year 4. (It's not for me to decide when graduates are permitted to sit for a bar exam, of course, or even whether requiring a bar exam as a condition of licensure continues to make sense. For now, I assume that licensing will be required to practice law and that most American states will require passing an exam as a condition of licensure.) Graduates who want the JD degree and education but do not anticipate taking a bar exam would save themselves the time and expense of attending an additional year of school.

Students who obtain the JD degree after two years would have an open-ended option to re-enroll at the same law school to complete supplemental pre-bar exam training via clinics, or externships, practicums, and the like. Alternatively, that training might be completed via certified, supervised work in live-practice settings. If that's the case, that is, if students are working, then the students should be paid. 


\section{Madison, Visions of the Future of (Legal) Education \\ Page 10 of 38 \\ March 20, 2014}

Format:

The academic year would be structured around quarters (9-10 week segments), offered year-round (i.e., Fall, Winter, Spring, Summer). If the school were located in a university (above, I assumed that it should be), and if the administrative structure of the university made that system infeasible, or if it proved to be a barrier to productive student engagement with schools and departments outside the law school, then a semester structure would be suffice, but one or more "short session" (2- or 3-week terms) should be built in to the program, between the main semesters and/or as midsemester breaks. ${ }^{7}$

\section{Content - Year One:}

This would be mostly classroom-based work but formatted so that simulation/role-playing, live experience interaction, and plain old field work would be a regular part of teaching. No classroom group would be more than 20 students. Some kinds of online/digital/recorded content delivery would be included, but the core of the model would be closer to a tutorial / seminar format.

There would be courses on governance (interdisciplinary blends of what is now constitutional law, civil procedure, and introductions to the administrative state, plus material on institutional design and political theory), on resource creation and allocation (replacing contracts, property, intellectual property (in part), and some of torts, and including foundational work in law and economics and cultural theory), and on civil and criminal justice (including theories of retribution and restoration). In total, those would provide three year-long substantive "tracks," which would be designed to interweave with one another rather than to constitute three separate and independent silos. There would a year-long track on institutional design and organizational behavior, to introduce students to business, government (including more material on the administrative state), and non-profit basics. All of this would introduce students to legal doctrine and methods - learning the methods and content of the common law, for example, is still important - while situating both in theoretical, historical, and practice-based context.

\footnotetext{
7 Stanford Law School recently reorganized around Stanford University's quarter system in order to facilitate inter-departmental student engagement.
} 


\section{Madison, Visions of the Future of (Legal) Education \\ Page 11 of 38 \\ March 20, 2014}

There would be a year-long track on leadership and personal and professional development, some but not all of which would be directed to ethical and identity formation issues. This is an area that law schools systematically ignored for decades, because large law firms preferred to take smart but "unformed" graduates, people who could "think like lawyers" but do little else, and "form" them in their own image. Law firms now rarely do that, and if law schools do not fill this gap, then we are literally dumping unformed graduates on a world that is all too happy to exploit them. In my law school, I'd make this facet of the program an explicit priority.

There would be a year-long track on intersections between law and technology (both computer technology and life sciences technology), teaching partly issues of substantive law and policy as those are now heavily influenced by technology and also issues of theory and economics (the logic of networks and codes) and topics of law and design (how law is in part a designer's discipline and how technology is an important tool in the designer's kit).

There would be a heavy, even intensive emphasis on cultivating interpersonal skills, particularly those that relate to service (serving and counseling clients, developing and exercising judgment, serving communities, serving the public good) and leadership (not so much "project management" and execution skills, but developing and using one's own voice in engagement with others), and on communication skills, particularly writing skills.

The curricular tracks would be coordinated so that every student would produce one three- to five-page written work product every week throughout the year. These assignments and projects would be distributed across all of the different domains described above.

There might be periodic examinations, and there might be year-end comprehensive examinations, or some sort of one-to-one portfolio assessment of each student by a faculty member.

\section{Content - Year Two:}

This year would be grounded heavily in advanced legal doctrine and theory taught via classroom-based, simulation-based experiential teaching. This would blend 


\section{Madison, Visions of the Future of (Legal) Education \\ Page 12 of 38 \\ March 20, 2014}

classroom reflection and analysis supervised by full-time faculty and practicum- and externship-based performance and guidance likely under the direction of well-trained practitioners / faculty partners. (Practitioners, judges, and others, as part-time adjunct faculty, would co-teach in partnership with full-time faculty.) These experiences could be organized around substantive themes interwoven with substantive law and theory: Wealth and power (an introduction to major portions of the regulatory state - health law, elder law, and tax law, for example); justice and dispute resolution (both public and private); international law and policy and global markets (again, both public and private); law and business and finance; innovation processes and practice. That is a non-exclusive list, and even these clusters are just tentative, preliminary thoughts. In effect, the second year would be a series (or a collection) of inter- and multidisciplinary electives. Teachers would be encouraged to include content from disciplines outside of the law school. Students would have to complete some number of "rotations" through a menu of these clusters.

The lessons of year one with respect to leadership and personal development in organizational and institutional context would be explicitly woven into the pedagogy of each "rotation."

The intensive writing experience would continue, with one short paper per week coordinated among the clusters.

In all, students would take three quarters of academic programming per academic year. The summer between year one and year two would be intended to provide students with some kind of so-called "real world" work experience, as it is today, but the curricular program might be designed so that academic year experiential progressions lead directly into a summer experience, or a summer experience might lead directly into the second year, or both.

At the end of year two, students would have to pass a set of comprehensive oral and written exams or undertake another comprehensive portfolio review with a member of the faculty.

And then they would receive their JDs. Graduates who do not plan to take a bar exam could begin (or continue, or resume) professional careers. 


\section{Madison, Visions of the Future of (Legal) Education \\ Page 13 of 38 \\ March 20, 2014}

Content - Year Three (and perhaps Year Four):

The primary purpose of the third year would be to equip law students with more refined, supervised knowledge of being a legal professional. Some number of hours or weeks or types of supervised experiential training would be required before a JD recipient would be eligible to sit for the bar exam. This would not in all cases make new graduates "practice-ready" (or even, in all likelihood, make many of them "practice-ready"), but it would bring many more of them to the point where they can usefully begin to earn a living in the legal profession or the "legal services industry." Forms of relevant experiential education might vary. Law clinics would be included. "Incubators" and "labs" and "model law firms" for law students (with live client or live business partner or technology developer etc. interaction, and with appropriate supervision) might also qualify and be part of the law school. Students who want to earn the JD degree would not have to complete these "experiential" years directly after completing the degree.

But the law school would not be the only provider of this kind of training. The law school would be one of any number of possible vendors of clinical or practical / experiential education. Experiences supplied by accredited and regulated non-law school vendors would qualify; a student who worked at a law firm as an unlicensed, supervised, junior practitioner would satisfy the requirement. Some of the inspiration for this comes from the Canadian "articling" model and some from the medical school MD model. The keys to making it successful would be ensuring that the experience is pedagogically meaningful (making it superior to what I understand to be flaws in the articling model) and not economically burdensome to the student (making it superior to flaws in the medical education model). Students could opt to satisfy the requirement by working professionally and getting paid. Or they could satisfy it within the law school setting and paying whatever tuition the school charges.

Students could opt to stay in school for a post-JD year (or even two) and not participate in an experiential program or rotation. Students could stay and develop expertise via the classroom in one or more areas of practice, or substantive law, or legal theory, or some other application of law.

More broadly, the law school would offer supplemental substantive post-JD programs in addition to the above. Some might target continuing education needs of 


\section{Madison, Visions of the Future of (Legal) Education \\ Page 14 of 38 \\ March 20, 2014}

the profession. In addition, after receiving the JD, students who aspire to scholarly careers could continue through "scholarly rotations" offered by the faculty, with supplemental writing and examination requirements leading to a JSD or possibly (in conjunction with other university departments) to a Ph.D. Students enrolled in the post-JD scholarly track might apprentice as teachers in the JD program, partnering with full-time faculty rather than (or in addition to) handling classes on their own.

\section{Summary:}

To be clear, this is not a model of how all law schools should be organized. It is only a model of one law school, that is, my own idealized law school, and only a sketch rather than a fully realized plan. Some of its proposed parts may be more attractive than others; some may not be attractive at all. Not all of its potential programmatic inconsistencies are worked out. I don't advocate reforming contemporary American legal education along all of these lines, among other reasons because the economics don't scale, even if they work at the level that I've described here. I have thought long and hard about the number of students, for example, and whether there would be a way or a reason to accommodate more people. I am not persuaded that there is. It is a boutique model, to be sure. And it should be obvious that in many respects it runs afoul of at least some and perhaps many existing regulatory requirements for law schools.

Still, whether or not this is a model that could actually be built, wholly or partly, is there something here that we could build on in today's system of legal education? I return to that question later on.

\section{Version 2.0: Reality}

In many ways the foregoing goes too far down the path of un-reality. In a different sense it does not go far enough in respecting what I think is much more likely to emerge in legal education. What follows next is a refinement and extension. Version 2.0 of the model, if you will. As with Version 1.0, the point of this exercise is not only to explore the blue sky aspects of what lawyers and law professors do. It's to see if the blue sky exercise leads to recognizing some things that we might do today that would help our students and the profession and the world they serve, and things that we may avoid. 


\section{Madison, Visions of the Future of (Legal) Education \\ Page 15 of 38 \\ March 20, 2014}

Version 1.0 framed a small, integrated two/three-year law school program that makes some substantial changes to the way things are usually done today. The JD degree would be a two-year program, but sitting for the bar would require a JD plus substantial "experiential" training, perhaps in a law school, perhaps elsewhere. The two-year program would be restructured. The first year would focus in part on "content," though in interdisciplinary blends rather than in classic doctrinal silos, and in part on tracks focused on personal/professional development, on technology and design, and on business, organizations, and management. Layered throughout would be heavy emphasis on communications skills, particularly writing. The second year would consist of a series of elective courses organized thematically — international issues, criminal justice issues, innovation and entrepreneurship issues, law and power issues, urban policy issues, and so on. Each "course" would be an experiential/classroom blend, with extensive use of simulations and role-playing and live-party interactions and a continuation of the focus on writing and communications skills. An elective post-JD year, required for bar admission, would feature clinics, labs, incubators, internships, practicums, and so on. The post-JD year would also include modules or tracks devoted to expertise in substantive areas of law or legal theory. Those could include scholarship and training of future faculty, leading to whatever extra degree or certification were required for admission to the professoriate. For them, a post-JD year might run into more than one year. All in all, this is a high-cost boutique model that would have to be subsidized to a substantial degree by a massive endowment.

Version 2.0 is oriented more to a prediction that to a recommendation. It would unbundle most if not all of this as well as much of legal education generally. What follows is much less prescriptive than version 1.0. Version 1.0 was (is) a first draft of what my own vision of a new law school. Version 2.0 is closer to what I think is coming to legal education.

I start with a question that is a cousin of the questions posed, at least implicitly, to a large number of professional disciplines, services, markets, and industries over the last 15 years - roughly since the emergence of the commercial Internet. Why do all of the functions of a law school, even a law school of the future, need to be provided in a single, integrated institution, by a single group of faculty? 


\section{Madison, Visions of the Future of (Legal) Education \\ Page 16 of 38 \\ March 20, 2014}

The JD degree is essentially a certification by some body (today, the integrated law school) that students have completed a certain number of credits in a certain knowledge domain. The contents of some of those credits are mandatory (legal ethics or professional responsibility, for example); the content of most of them are optional. Let us imagine for now that the certification function remains applicable and relevant, but that students could obtain certification from some appropriate institution by virtue of having completed the course credits or other activities as they wish, in whatever time frame that might be specified (two years sequentially? Or within a three- to fiveyear window?), and in whatever venue or venues they prefer. That institution might be a university. It might be a stand-alone school. It might be a state bar association or the Supreme Court of a state. It might be located online, or outside the US, ${ }^{8}$ or both. It might be something else entirely.

Some or all relevant propositional knowledge could be obtained online. Massively Open Online Courses (MOOCs), better conceptualized and organized than they are today, might serve, but MOOCs offer only one way of organizing online information delivery. Writing and communications education could be obtained in writing academies (for example) that would serve not only future lawyers but also future engineers and managers and schoolteachers, offering both general writing instruction and specialized versions for different professional disciplines. Leadership and personal and professional development training could be supplied by extensions of existing dedicated programs that provide exactly that, or by business schools, or by colleges, or by some combination of these things or by new ones. Experiential training, the sort of thing provided by today's law clinics, could be supplied by apprenticeships within law offices and law firms or within other organizations and institutions that deal with law, legal services, and the legal profession. Elective modules in different disciplinary domains could be provided by specialized providers within each domain. Overlaps among domains and creation of new domains would be expected and accepted.

Designing pathways through this stuff so that the resulting certification looks more like an educational program and less like shopping for legal education at Costco, with lots of disconnected chunks of things dumped in your educational cart, would

${ }^{8}$ For example, the Peking University of Transnational Law is seeking American Bar Association accreditation. 


\section{Madison, Visions of the Future of (Legal) Education \\ Page 17 of 38 \\ March 20, 2014}

take some time and care." A "law school" dean, for example, would be a curator or brand manager as much as and perhaps even more than an educational leader, strategist, and visionary. A given "law school faculty" could be far less than a group of actual classroom teachers and a so-called "company of scholars." The very word "faculty" implies a group of people bound to an institution. But the institution would be little more than a brand and a certifying agency. Individual teachers / scholars would certainly exist, but they would be free agents supplying individualized teaching and learning services, certified as "acceptable" (or better) by some other authority. Readers familiar with the history of higher education will note the "back to the future" character of this. Even if some people think that law schools (and a lot of higher education) already operate in nearly this mode, I'm trying to push it back farther, to the earliest roots of the university. Technology brings us full circle; my Version 2.0 reads quite a bit both like Bologna in the 12th century. It also reads like Clark Kerr's semi-serious, dystopian description of a university as "a series of individual faculty entrepreneurs held together by a common grievance over parking."

Providers and consumers of educational resources would create and share pools of knowledge and expertise across geography and time (teachers in one venue, perhaps live and perhaps recorded, could work with students in different venues and perhaps at different times) rather than meeting in a single place at single time under the umbrella of a single school. The idea of cohorts of students moving in sync through an institution, as a "student body," would fade away.

Undoubtedly there would be a lot of trial and error. Certification authorities might end up competing with each other. Bar admission, if it remained a necessity, could specify certification at some level. Clients and consumers might demand higher levels of certification, whether for prestige purposes or quality purposes or both. Prestige hierarchies would not go away, but they and their constituents might move around a bit.

My guess right now is that if my Version 1.0 of a future law school is a highpriced fantasy, my own upscale, romanticized version of how I would spend a lot of

\footnotetext{
${ }^{9}$ Cynics would note that many of today's law schools operate as little more than certifying bodies with respect to the courses taught by their faculty - but without that time and care.
} 


\section{Madison, Visions of the Future of (Legal) Education \\ Page 18 of 38 \\ March 20, 2014}

money, then my Version 2.0 is closer to a low-priced version of what I think will actually emerge over some unknown period of future years.

My armchair forecast should not be mistaken for advocacy. There are lots of reasons to be skeptical of the efficacy and efficiency of Version 2.0 in producing anything close to results that would benefit society, in terms of people prepared to do the many things that society may want and need from those with legal training. If law degrees are in effect brands supervised by dis-embodied certifiers, then they are exposed to many of the costs of a trademark system (particularly the failure of the certifiers, or mark owners, to resist economic imperatives to underinvest in maintaining the quality of their goods and services) and few of its benefits (quality assurance, both in the sense of quality as "free of errors" and quality as "consistency"). Who would be in a position effectively to police both sides of this marketplace - the materials on offer to potential students, and the skills and services they offer as new graduates?

I share a lot of that skepticism, as do many who are skeptical of the future of higher education in general. But if one way to understand Version 1.0 is "this is what I'd be inspired to build," a second and perhaps more realistic way to understand that vision is by contrasting it with an apparently dystopian Version 2.0. Can legal education move in part toward what's attractive about the former? Partly that requires optimism about what Version 1.0 would bring; partly that requires pessimism about the drawbacks of Version 2.0.

\section{Visions}

I have been presenting back to front, in a manner of speaking, putting the more detailed conclusion before the more general introduction and the evidence. In Parts I and II I have described a law school or schools of the future purporting them to be visions, but in truth they are blueprints rather than visions. The descriptions are ways of getting things done; they aren't the things themselves that need to be done. Visions - programs that translate backward into plans of action, organizational, institutional visions - are things that need to be done, and for that reason they are not so detailed. Moreover, if there is any hope for a vision becoming reality, then that vision cannot be mandated from above or by one particular source, let alone by me. Visions do not come on stone tablets, and they do not get carried down from the 


\section{Madison, Visions of the Future of (Legal) Education \\ Page 19 of 38 \\ March 20, 2014}

mountain top. As much wiser people than I have written, shared visions get built, ${ }^{10}$ and they are built from individual visions, and from values, purposes, and big themes and goals.

In those senses, my vision is only a starting point for a conversation about a shared future. It derives from a set of intuitions about what I do and what I want to do with my students, now and in the years to come, things that are rarely captured in conventional discussions of law school pedagogy and exam writing; about faculty identity; about the types of jobs that students should aspire to securing within nine months of graduating; about the cost of legal education; and about the organizational forms in which legal services are delivered and which new graduates are hired. Those things are important to many, many people, and asking and answering questions about those topics seems to dominate almost all conversations about the future of law schools. In their usual form, at least, they are not that important to me. Answers to questions about cost and careers, about and faculty and pedagogy, are not the places to start. They are means; they are not outcomes. And if anything new and important is going to come of legal education as a part of law and society, then a vision based on outcomes is needed, a vision that will both motivate and tap into existing motivations to make whatever changes that are coming. "Markets" in some abstract sense will push law schools forward (or push some law schools out), but vision will pull them. ${ }^{11}$

Here I dive ahead with some thoughts on outcomes. What results are important to me? What do I prioritize? Where do I start? This, and here: I want my students - and, because I have the grandiose ambitions on display in this Essay, all law students - to graduate with a sense of overarching personal and professional capability and self-confidence in their fundamental power to change the lives of the people that they work with. I want that sensibility to exist in a deep and essential way that can pull them through the troughs, valleys, and crises of professional, personal, and social lives and that are too often associated with not remembering the black-letter

${ }_{10}$ See, e.g., James C. Collins \& Jerry I. Porras, Building Your Company's Vision, Harvard Business Review (Sept. 1996).

${ }^{11}$ Bill Henderson's A Blueprint for Change, 40 Pepperdine L. Rev. 461 (2013), speaks of the "12\%" of the law faculty at a given law school who are likely to lead innovation at that school; that $12 \%$ are the "positive deviants," to use management jargon, pushing "positive deviance" within the organization. What positive deviance captures is a vision of the community's capabilities and future that is grounded in the values, experiences, and knowledge of the community itself. 


\section{Madison, Visions of the Future of (Legal) Education \\ Page 20 of 38 \\ March 20, 2014}

rule, not knowing how to draft a discovery plan, and other, similar nuts-and-bolts issues. This is far more than "knowing how to interact with the partner" and "how to interview a new, prospective client" and "how to draft a simple estate plan," although all of those things may be subsumed within the broader theme. In a complex world, law school graduates need simultaneously to understand the globe and the neighborhood; they need to possess agency to act effectively in large settings and small ones. And they need to possess agency with respect to their own lives and careers. Perhaps it sounds self-aggrandizing to claim that giving law graduates that agency is my vision for what I do, but that's my starting point. Every teacher has one, whether or not he or she realizes it and articulates it.

I alluded earlier to the changing nature of what lawyers do in the world, the evolving nature of the organizations and institutions through which they impact people and change lives. Law school career services offices are gradually waking up to the fact that far fewer students will build careers right out of law school by soliciting offers to start work as junior lawyers in law firms; "on campus interviewing" by large numbers of firms and students is fading in importance. Change, in other words, extends to the core of law graduates' professional identities. Law students today are graduating into a world of perpetual free agency. Not in the celebrity athlete sense, but in the make-your-own-job-and-career sense. For the last several decades, the mythos of the profession held that new graduates were absorbed into the bosom of law offices and law firms, to be groomed, trained, and cultivated to maturity. Law schools loosed blocks of law student marble from the earth; law offices saw lawyers in the marble and carved to set them free. If that was ever really true for a large proportion of the $20^{\text {th }}$ century profession, it is no longer true today. The agency that I described in the preceding paragraph - the power to effect change in the world - now has to begin to be developed on an individual by individual basis, as part of the student experience, rather than as part of post-graduate professional development. New law graduates are obliged and expected to build their careers and lives - to be authors, in a sense, perhaps - to a much greater degree than most living lawyers have ever had to grasp, until relatively recently

Recently, at the Concurring Opinions blog, a group of my law professor colleagues critiqued a terrific new book by Orly Lobel (a Professor at the University of San Diego), called Talent Wants to be Free: Why We Should Learn to Love Leaks, Raids, and Free Riding (Yale 2013). The thesis of the book is that law and public policy should 


\section{Madison, Visions of the Future of (Legal) Education \\ Page 21 of 38 \\ March 20, 2014}

be designed to enable "flows" of talent. Firms, industries, markets, and individuals will be better off overall and in the long run.

In the abstract, that's a thesis that appeals to me. I grew up in the 1960s and 1970s in what became the Silicon Valley, and I practiced law there for a while. The economic vibrancy of the place is hard to miss, and much of that vibrancy is properly associated with Californian law, policy, and culture that favor open "flows" of talent. When you look at the question of "flow" from the standpoint of the "talent" itself, the benefits of openness sometimes shrink. Not everyone has the wherewithal to take advantage of nominally open doors. "Flow" works when the labor pool and individuals within it have the capabilities that make openness and flows pay off. If you're an entrepreneur (a "founder" in contemporary jargon) or an innovator, open systems can work in your favor.

But just as California's economic vibrancy is hard to miss, its income and cultural inequalities are hard to miss, too. Not everyone is an entrepreneur or an innovator; not everyone is a sought-after engineer. If you're in a disfavored category, culturally speaking, then "talent" does not necessarily want to be free so much as "talent" wants a job and an income. What about hairdressers, who are often (though not in California) subject to restrictive covenants? They, too, can benefit from talent flows - but only if and when hairdressers not only know how to cut hair (and aren't held back by professional licensure requirements) but have the self-awareness, courage, spirit, and resources to say, when it is appropriate, "take this job and shove it. I've found a better gig." And start a new salon in a new town.

Lawyers, especially young lawyers, are in my experience too often saddled with an absence of that self-awareness, courage, spirit, and sense of their capabilities. In the resource space, they are also, of course, saddled with enormous debt, and the two problems, while related, are distinct. I know plenty of lawyers, at all levels of seniority, who are not burdened by the financial constraints of student debt but who still lack much of the spirit that I am referring to here.

Can a law school do more - much more — not just to teach the forms (and form books) of practice, but also the underlying spirit of self-assurance and agency that new graduates need in order to progress professionally and personally? 


\section{Madison, Visions of the Future of (Legal) Education \\ Page 22 of 38 \\ March 20, 2014}

I believe that it can, and I believe that it should. That spirit can be taught; it can be learned. With my students today, I sometimes share a story from my own junior days. A senior lawyer told me to draft a motion for something or other. I had learned that the fastest way to put a motion together was to pull appropriately-titled documents from a form book in the firm's library, modify them as needed, draft a relevant pointsand-authorities, assemble needed evidence (testimonial declarations and the like), then file. But I came back from the library empty-handed; there was no form for the motion requested by the senior lawyer. What should I do, I asked, when there appeared to be no form of motion to match the request?

The senior lawyer patiently sat me down and explained that a motion is simply a way of asking a court to give you what you want. You can ask for anything, within reason (more or less). The art of lawyering lies in how you ask and how persuasive you are. Maybe you have a statute or rule on your side. Maybe there is precedent. Maybe the evidence is really compelling. Add it up! But don't be limited, he instructed, by what the form book writers tell you.

This, I tell my students, was a revelation to me. (It is only partly an excuse that my Civil Procedure experience in law school consisted of exactly one semester, which focused almost entirely on the due process dimensions of attachment orders and Rule 23.) I cannot say that I was a changed lawyer after that conversation, but the dialogue certainly re-aligned my sense of my own professional powers.

I've been noodling on this agency question for a while and trying to figure out how to weave it more explicitly into my professional life. Years ago, I changed the way I teach my "standard" large law school courses to bring more of this sensibility to my students' experiences. ${ }^{12}$ I direct a program at my law school (the "Innovation Practice Institute" at Pitt Law) that organizes all of its programming around that theme. Most recently, I've started teaching leadership skills to law students. ${ }^{13}$ Initially I was working then with very small groups of students in one-day seminars; I am now offering a five-week extracurricular "leadership skills" program to anyone in the law

\footnotetext{
${ }^{12}$ For a summary, see Michael J. Madison, Writing to Learn Law and Writing in Law: An Intellectual Property Illustration, 52 St. Louis Univ. L.J. 823 (2008).

13 Michael J. Madison, Leadership for Lawyers, madisonian.net, http://madisonian.net/2012/03/06/leadership-for-lawyers-2/ (Mar. 6, 2012).
} 


\section{Madison, Visions of the Future of (Legal) Education \\ Page 23 of 38 \\ March 20, 2014}

school community. The reading list includes Caruso \& Salovey, The Emotionally Intelligent Manager, Hesselbein, My Life in Leadership; and Kolditz, In Extremis Leadership, among other things. I am using roughly one text per week as a prompt and primarily for reflection and discussion regarding the attendees' own experiences. ${ }^{14}$

This is not a for-credit activity (not now, anyway); I'm just volunteering a little time and hoping that some students and perhaps other members of the law school community - perhaps some of our recent graduates - will volunteer some of theirs. I'm aware that some law schools are tackling leadership questions in a much more thorough way. Among law schools, Elon, in particular, seems to have a pretty thorough commitment to the issue. But I haven't searched comprehensively. Maybe I've missed some obvious candidates.

Not every law student wants to be a "leader." The point of my mini-course is not to train a bunch of new presidents and chairs of the board. And there is essentially no law- or law school- or legal profession-specific content in my curriculum. This isn't about "lawyers as leaders," though if one of the outcomes, well down the road, is leadership in law practice settings, that's great. The true point is to expand the students' collective sense of themselves, of their histories and their experiences, and of their futures. Their values. Their capabilities. Their visions of themselves.

Back in 2008, Bill Henderson (Indiana University) wrote about the benefit to our students of faculty investments in what he called "school-specific capital," sometimes to the detriment of individual faculty members looking to maximize their value on the lateral job market. ${ }^{15}$ I wrote a long reply on my own blog, because his question triggered a bunch of thoughts about cultivating and leveraging institutional capital in general. Or what I'd call building a shared vision for the future. An extended excerpt follows, in order to explain how I connect my interest in leadership with my interest in and visions for legal education and law schools. On my blog I borrowed an analogy from the challenges faced by Pittsburgh, where I live and work, in emerging

\footnotetext{
${ }^{14}$ In other words, this is not a reading group. And suggestions are welcome.

15 Bill Henderson, Law Professor Free Agency and "School-Specific" Capital, Legal Profession Blog, http://lawprofessors.typepad.com/legal_profession/2008/08/law-professor-f.html (Aug. 13, 2008).
} 


\section{Madison, Visions of the Future of (Legal) Education \\ Page 24 of 38 \\ March 20, 2014}

from its steel-history shadow and converting its enormous well of cultural capital (Pittsburghers around the world are passionate about Pittsburgh) into tangible, economic capital:

In Pittsburgh (the region, not the law school), we have institutional capital coming out of our ears. Urban partisans from around the world will disagree, but I'll assert that present and former residents of Pittsburgh (and there are an awful lot of the latter) love this area (and its food, its football team, its slang, its traditions) like no other population loves its city. As sports fans know, the core of the phenomenon is 'Steelers Nation' and its outposts around the world, but Pittsburgh culture runs deeper and broader than that.

Where does that institutional capital come from? From two things:

One, it comes from the community's deep and abiding absorption in the history and mythology of Pittsburgh: The power of its industrial heritage of a century ago, the model-of-urban-renewal experience of the 1950s, the 'City of Champions' experience .... Professional sports in particular play an unusual role in Pittsburgh's narrative: The emergence of the Steelers after decades of ineptitude; the Pirates' World Series win over the Yankees, Clemente, and the Pirates' later We are Family era; Lemieux, and now Crosby and Big Ben.

Two, it comes from an economy that for generations has made it inexpensive to stay and costly to leave. Real estate in Pittsburgh is dirt cheap compared to most other cities in the U.S. Pittsburgh doesn't need long-term contracts to keep people here; many people literally can't afford to go anywhere else. That might lead to a lot of defensiveness and anxiety, and at times it has. But it also produces an enormous well of regional pride. Pittsburgh's blue-collar self-image is pride born of necessity. 


\section{Madison, Visions of the Future of (Legal) Education \\ Page 25 of 38 \\ March 20, 2014}

But all the regional pride in the world won't turn the tide and make Pittsburgh a roaring economy any time soon. In my Pittsburgh blog persona, with a few colleagues I think about how to activate that institutional capital to benefit the city - to get people to return, or to invest (time, money, and skill) to move the region's economy forward. It's a difficult problem, and one that's not unique to Pittsburgh, but it's a problem that leadership cannot solve. No amount of public persuasion - and there has been a lot of that - will motivate a community to wake up and simply align Pittsburgh's interest with their interest.

How do we get people to put on their institutional hats?

What has to happen ... is that the community needs to perceive that if they do align the two, the proverbial pie gets bigger. ... Right now, the prevailing wisdom in Pittsburgh is that risk (i.e., aligning oneself with the institution) is a bad thing; life here is a zero-sum game. We're immensely proud of Pittsburgh, and we're not going anywhere (either physically or conceptually), but we're a region of defectors.

What does it take to make that happen? I've concluded that the city basically cannot change itself. Pieces of the city can reinvent themselves, and ultimately, perhaps, reinvent the whole. Right now, certain Pittsburgh populations - economic and cultural communities - are positioning themselves as cooperators, and they are slowly appropriating and conserving Pittsburgh's institutional capital: certain high-tech entrepreneurs, certain sectors of the higher education community, the entertainment industry (such as it currently is). That institutional capital is being reinvested, but largely only in those communities. Pittsburgh's zero-sum, risk-avoiding, "defector" population will, over time, simply fade in economic and cultural importance. That's the theory, anyway.

Can I translate that back into law school terms? Not in much detail. But there are a few lessons, I think. 


\section{Madison, Visions of the Future of (Legal) Education \\ Page 26 of 38 \\ March 20, 2014}

One is that a law school would do well internally to highlight successes in its institutional history (but not bury failures - those are part of the mythology, too), and to promote and continue rituals that connect past to present. Never do that mindlessly; change and adaptation and all that. The University of Pittsburgh and its law school partake deeply of much of Pittsburgh culture, but in my first years at the school I was often at a loss to understand aspects of the faculty's behavior that were obviously grounded in its history and culture. In Pittsburgh more broadly, newcomers to the city often look around in bewilderment at the city's obsession with the steel industry - even though that industry has all but disappeared from the area. But the history of steel is vital, and dismissing steel as an anachronism would be a terrible mistake. Teach the newcomers, and have them teach their successors! Create visible markers of that history.

Two is to create an environment where it is inexpensive to stay, and expensive to leave. Are there ways to endow individual faculty members with a share of the prestige value of the institution? Most law schools are part of larger institutions; does the larger institution have prestige markers that it can share? Most law faculty can translate all of that into more and less concrete conditions. Some of this is merely informational (how much do you know about what is happening elsewhere at your school?); some of it is (within limits) participatory (how often are you invited to participate in events connecting the school with its alumni?); some of it is architectural (in what ways does the facility naturally bring the faculty together, and in what ways does it separate them?).

Three is to accept that some people are natural cooperators and some people are natural defectors; coercion can solve problems at the margin - perhaps - but if a stable solution is to be found, it needs to arise largely organically. Institutional capital will accumulate and influence behavior when there is some relevant mass of people 


\section{Madison, Visions of the Future of (Legal) Education \\ Page 27 of 38 \\ March 20, 2014}

who take it upon themselves to make it so, and to act accordingly.

Some people will, over time, opt out. ${ }^{16}$

Borrowing from that comment leads me to this. A vision of the future of legal education needs to be built from the ground up, and it needs to be built out of commitments of those who wish to step forward and participate in the visioning process. What's past is prologue; many of those commitments are already present, waiting to be leveraged for future benefits and perhaps to be made more salient than they have been previously. Some of those will be novel, and with them the challenge is to weave them productively into the old without sacrificing existing strengths. Anyone interested in moving the institutions of the legal profession forward would do well by all of us by putting those things explicitly on the table.

\section{Values}

I burrow one step further, having started with my vision, then talking about vision in general, and now, in this Part, grounding vision in values. Values drive vision. What interests me and inspires me in terms of vision and outcomes is grounded in what managers call a value set. When I think about the future of legal education when I think about the future of higher education in general - I don't start with premises about changing job markets or changing technologies or changing interests and talents of Generation X, or Y, or Z. I don't start by looking at the impact of disruptive innovation on the legal profession. I start with premises about who our present and future students are, who they want to be, and who they will be. I start with premises about who we are as educators, and who we want to be. Why do we do what we do? Why do I do what I do?

The most concrete parts of this Essay, Parts I and II spoke about market realities largely out of a sense of necessity. The conversation about vision in Part III explained how my vision came about and how any vision could come about. In this Part, I offer a more personal reflection about the values that should drive a conversation about vision. None of this necessarily reflects what may be happening at

16 Michael J. Madison, Law and Institutional Capital, madisonian.net, http://madisonian.net/2008/08/13/law-and-institutional-capital/ (Aug. 13, 2008). When I wrote that, I had not yet learned the phrase "positive deviance," let alone read about Henderson's 12\% model. 


\section{Madison, Visions of the Future of (Legal) Education \\ Page 28 of 38 \\ March 20, 2014}

my law school or any law school today. This is only the world as I see it, and in some respects the world as I wish it to be.

Any vision of the future of law schools cannot succeed over the long run cannot be effective and durable with respect to whatever aspirations its creators set for themselves - unless it is grounded in shared values. Some people will disagree with that; to many, the point is a sound business plan. Taking today's market as a baseline, that might mean fewer law schools, cheaper cost of attendance, fewer graduates, fewer but better paid lawyers. But I'm going to stick to my guns, and to values, not economics. A vision of fewer and cheaper law schools and fewer and better paid lawyers is obviously a legitimate one, but that vision is an output of the process of deciding what legal education should be, and it's only one possible output. It's not a starting point.

Today's American law school is essentially a Langdellian law school, with some clinical bells and whistles appended. The Langdellian law school has endured for more than 100 years not because it represents a sound business plan; the purposes and "business" conditions that grounded Langdell and Harvard's then-president, Charles Eliot, have long since changed dramatically, many times over. Bringing law (and medicine) fully into a modern research university was Eliot's goal, and that ship sailed and landed long ago. But the values of the Langdellian model have inspired and endured, idealizing law as an "objective" discipline that could be abstracted and synthesized from experiments, known as cases, teaching a mode of analysis that would span all fields of legal practice and justifying law's place in universities. Legal education in that mode fit hand-in-glove with the increasingly bureaucratized, hierarchical domain of private law offices and law firm practice of the early $20^{\text {th }}$ century that delivered, to use a romantic phrase, "bespoke" or custom legal counseling. Bespoke "efficiency" in a managerial sense is too simple and reductive a phrase to capture the entirety of this history and the value system that underlay it, but it's not too far from the mark.

Before putting $21^{\text {st }}$ century institutional and pedagogical innovations into practice, it's worth spending some time and space re-considering the Langdellian premise, as it has come down to us, and its foundational values. I don't mean to rehash critiques of Langdell and the case method. Instead, I want to ask, briefly, why we (as law professors) do what we do today? What binds us together? Here's a cheap 


\section{Madison, Visions of the Future of (Legal) Education \\ Page 29 of 38 \\ March 20, 2014}

version of the standard account. One chief purpose of law school today remains to teach future lawyers to "think like a lawyer." That's not an empty phrase; Fred Schauer has a nice recent book (Thinking Like a Lawyer: A New Introduction to Legal Reasoning (Harvard 2012)) that explores it in great detail. Even its adherents among educators, however, recognize its limitations. As a second purpose, therefore, "thinking like a lawyer" must be coupled, educationally speaking, with "doing the things that lawyers know how to do," such as file and defend lawsuits and prepare estate plans and document transactions and so on and, at a more complex and higher level, guide the affairs of institutions, organizations, enterprises, and governments. A third and usually final purpose of law school is to ensure that future lawyers know that they should behave ethically and virtuously, both internally, with respect to the legal system itself (offering proper respect for adversaries and for courts, for example), and externally, with respect to society at large. Somewhere in between purposes two and three there is often recognition that a key dimensions of "lawyering" — "competencies," in contemporary jargon — involve other-directedness (putting others' interests above one's own), and judgment (the notion that legal counsel often involves more than ruleapplication and rule-following) and related things. We need to teach that, too.

If these themes are widely shared among both law teachers and members of the legal profession, and I think that they are, these are mostly goals, or outcomes, not values. I'm yawning. I can't and don't object to helping my students achieve these things, and I do them in my teaching, or I try to (most if not all law professors do, I believe), but I'm not inspired to come to work and to my classroom in the morning by the prospect of teaching another batch of law students to think like lawyers.

And the point of a shared values discussion should be, in my view, about inspiration. I'm hard pressed to detect a set of shared values in today's system of legal education, something that inspires me and inspires me to inspire others.

To get to inspiration, I shift the frame a bit. Who are the people entering law study, who are the people entering the legal profession, and how should those of us who teach law think about what we do to shape those people? Who are we, as the teachers? How do we think about what we do, and who we are?

Here's my theme, my word. I didn't originate it; I simply want to claim it. Service. Law - becoming and being a lawyer, being a member of the profession or 


\section{Madison, Visions of the Future of (Legal) Education \\ Page 30 of 38 \\ March 20, 2014}

the "legal services industry," being a law teacher — is about service. As a young lawyer, I practiced in a small firm in San Francisco that supported a range of clients - small; large; elite and corporate; Mom-and-Pop businesses; individuals. I struggled a bit, to be honest, with what I was supposed to do and with who I was supposed to be, and I occasionally struggled aloud. A partner in the firm took me aside one day and quietly shared a piece of no-nonsense piece of wisdom that I've remembered ever since: "It's a service business." If that's not you, then this — being a lawyer — isn't for you. The only questions are who you're serving and how.

As law professors, we serve. We teach our students to serve. Better: we are inspired to serve, ourselves, and we inspire our students to serve. We share a value: service. We pass that value on. To me, that's the core. There are other values in play. But this is where it starts; my idealized law school of the 21 st century turns out to be novel in many ways but traditional, even backward-looking, in this one.

It may be the case that the re-framing matters only at the edges, in terms of an educational program, but the edges are where change begins to take hold. ${ }^{17} \mathrm{I}$ think that the edges are extremely important, for the following reasons.

It has always seemed to me that the Langdellian model and its accompanying purposes took (and take) entering students essentially for granted. To revise the sculpture metaphor I used earlier, they are wet clay, in a manner of speaking, to be molded to suit the profession, but clay of a specific sort: clay primed by pre-legal education (college, required by the model) to think and reason and react in essentially and mostly mature and adult ways. The model posits college as the locus of most relevant socialization and maturation processes; legal education was and is meant to be essentially value-neutral with respect to students' personal and social identities. For decades, the view of the profession seemed to be that if students graduated full of legal reasoning skills but incomplete social and emotional powers, that was mostly all to the good; at least, it was not harmful. Why? Because the Cravath model of law firm practice, which married the Langdellian model in the early 20th century, assumed responsibility not merely for teaching new graduates to practice law but to complete their shaping as professionals and as people. As recently as the late 1980s, and probably

\footnotetext{
${ }^{17}$ Cf. Henderson, supra note 11.
} 


\section{Madison, Visions of the Future of (Legal) Education \\ Page 31 of 38 \\ March 20, 2014}

later, diluted versions of Langdell-plus-Cravath still dominated law firm and law office hiring across a great deal of the American legal profession. ${ }^{18}$

The Langdellian model is far from dead, but the Cravath model is either going or gone, for all intents and purposes. There are very few remaining law firms or practice settings of any other sort that are willing to underwrite the professional and personal development of its new hires to anywhere near the degree that they once were. New lawyers are not expected to be "practice-ready" in every case, but they are generally expected to be "life ready": responsible, capable, self-directed when appropriate and other-directed as needed, independent when necessary and collaborative otherwise. On that "life-ready" scorecard, there is a clear gap. For some time, law schools have been graduating new lawyers who are equipped formally for the intellectual rigors of law practice (that, at least, is what law faculties tell themselves), but who are at best incompletely equipped to mature into well-functioning professionals across these dimensions. The Carnegie Report of 2007 identified part of this problem by identifying a "professionalism" or "professional identity formation" apprenticeship that should form an explicit part of a law school's curriculum, ${ }^{19}$ but it missed a key point. Law school graduates need to learn not just who lawyers are, but who they are.

I'll translate that diagnosis backward. In my law school of the future, I'd ensure that the program did everything possible to produce graduates with "life capabilities," so that their law-specific intellectual training resonated with a broader set of cognitive, psychological, and social skills permitting each person to have full access to (a) personal and professional success and (b) the kind of impact on society - access to justice, actual justice, improvement in the lives of those around us - that the legal system is meant to provide. The modern "purposes" of a legal education (see above) should, in my view, be coupled with a deeper grounding in how our students can actually become both the lawyers that society needs and wants and the people that they want to be.

\footnotetext{
${ }_{18}$ My first law firm, the place in San Francisco where I heard the "service" mantra for the first time, only hired new associates from a small number of elite law schools and Northern California law schools and set strict class standing cut-offs for graduates of each of them.

19 William Sullivan, Anne Coby, Judith Welch Wegner, Lloyd Bond \& Lee S. Shulman, Educating Lawyers: Preparation for the Profession of Law (2007).
} 


\section{Madison, Visions of the Future of (Legal) Education \\ Page 32 of 38 \\ March 20, 2014}

In one sense, all of this sounds like a load of vague and idealistic babbling. At most, I've said merely that law school should not be the "value neutral" place that the modern version of the Langdellian model, it seems to me, implicitly endorses. To avoid that problem, and to make what I am saying in this Part more concrete for now, in practice, I'd translate my prescription more or less as I've described in Part I above, by reducing the amount of time that law schools spend teaching propositional and analytical knowledge and by increasing the amount of time immersing students in social, business, organizational, and technological dynamics. And, to push the innovation one significant step further, I'd focus students' interest and attention on questions of personal capability, agency, and leadership. Students do not come to law school understanding much of the "why?" or "how?" of who they are and who they might want to be as members of the legal profession. At least, few of the students I've met over the last 15 years, at four different law schools, have come to school with that understanding. (Maybe students of earlier generations once did; I can't know.) I would make helping students grapple with those questions a central part of legal education.

As I wrote above, much of this may come down to tweaking things at the edges, particularly to begin with. In time, I would hope that this view plays a more central role in legal education. Either way, I contrast my point of view with at least a couple of others that I have seen expressed recently in popular debates about what law schools should be or should do.

One alternative is a technocratic view of law and lawyers that appears to align legal education more or less explicitly both with technologically-influenced disruption in the legal profession and with the techno-utopianism of the Silicon Valley. The argument goes something like this: Legal problems are design problems; the new shapes of the legal profession present new design challenges; new lawyers should be trained as designers. The best-known proponents of this view in legal education today are the leaders of the ReInvent Law project at Michigan State's law school. ${ }^{20}$ As I understand this view, as educators we should be taking cues from leading designers (think like Silicon Valley thinks) and from those who educate designers (teach like MIT

20 See Andrew Benedict-Nelson \& Daniel Katz, Recalculate the Future of Law, http://www.theinsightlabs.org/research/recalculate-the-future-of-law/ (Nov. 22, 2013). Richard Susskind is the thought-leader in this area. See Richard Susskind, The Future of Law: Facing the Challenges of Information Technology (Clarendon Press 1998); Richard Susskind, Tomorrow's Lawyers: An Introduction to Your Future (Oxford 2013). 


\section{Madison, Visions of the Future of (Legal) Education \\ Page 33 of 38 \\ March 20, 2014}

thinks). Out with the humanities; in with engineering. Less visionary but no less ambitious law schools are likewise embracing law-and/as-technology. ${ }^{21}$ The obvious but crudest payoff of law-as-engineering is this. Law students need to understand the role of technology in society so that they can help techno-innovators make lots of money delivering legal services in new packages and, if all goes well, make lots of money themselves.

The great thing about this approach is that it's terribly sexy and exciting. It's hip. It's modern. It responds to what seem to be the truths of the marketplace. Students seem to love it, so it meets the need to inspire them. (Or at least some of them.) Donors seem to be attracted to it. Folks who see lots of technologicallymediated disruption in the legal services industry are prone to think that it's a logical next step. ${ }^{22}$ I tend to see a lot of disruption, too (those folks are not wrong), so I'm sympathetic to this move. Law-as-engineering has a lot to recommend it.

I'm sympathetic, but I also object. Not to the details, but to the values. I've shifted the frame from lawyers-as-engineers to law-as-engineering because I don't think that you can aspire to the former without accepting the latter. It's a choice about values as much as it's a choice about training, if not more so, and the values span both practice and content. As important as it is for lawyers and law students to understand technology and its uses, misuses, and effects, law-as-engineering is a badly one-sided view both of the legal universe specifically and of the social universe in general. If this is inspiration, then it's inspiration of a strange sort. Partly, of course, it doesn't inspire a lot of people; partly, it inspires in some specifically problematic ways. Silicon Valley ideology is a close cousin - social problems are simply design problems - and the general Silicon Valley strategy (and ideology) is not a panacea for the problems that the Valley itself claims to be solving.

21 See, e.g., Camille Nelson, Law schools can't sleep through the technological revolution, ABA Journal, http://www.abajournal.com/legalrebels/article/law_schools_cant_sleep_through_the_technological_ revolution/ (Nov. 7, 2013).

22 See Bill Henderson, Bringing the Dismption of the Legal Services Market into the Law School Classroom, The Legal Whiteboard http://lawprofessors.typepad.com/legalwhiteboard/2013/11/bringing-thedisruption-of-the-legal-services-market-into-the-law-school-classroom.html (Nov. 23, 2013). 


\section{Madison, Visions of the Future of (Legal) Education \\ Page 34 of 38 \\ March 20, 2014}

Here, I'll align myself with the critiques offered by my Silicon Valley contemporary George Packer. ${ }^{23}$ In a nutshell, he sees the Valley being consumed by a conscious inattention to distributive values. ${ }^{24}$ Valley history aside, great engineering cannot exist, so far as I can tell, without humanity (let me re-phrase: without the humanities). To build on an old joke, some of my favorite MIT designers are humanists. And most of my reading about design has focused on people like Donald Norman and Henry Petroski, who are, in my estimation, as sensitive to humane aspects of technology as to its functionality. Lawyers may read Foucault or disregard Foucault as they wish, but to put the matter bluntly, engineers need the arts as much as artists need science and technology. Which is to say, each ignores the other at their, and society's, peril. Law-as-engineering, lawyers-as-engineers, or legal techno-centrism risks suffering from precisely that ignorance.

I also contrast my view with a second alternative, which aligns the current ills of legal education with the diminished public stature of lawyers in society. This is a legal exceptionalism argument, and it runs more or less like this. If what we want is a sense of purpose and hope for students coming into the profession today, then what we should offer is a re-constructed vision of the lawyer as "architect of a just society," to borrow a phrase from one recent thoughtful op-ed by a law school dean. ${ }^{25}$ If we as legal educators can re-shape public perceptions of the legal profession, that is, if we build it - a place where students can become Daniel Kaffee, if not Atticus Finch - then both the educational system and society itself will recover.

This is a kind of "if you build it, they will come" inspiration. Law needs to recapture its nostalgic self. Law schools should be Fields of Dreams. I do like the

\footnotetext{
23 George Packer, Change the World, The New Yorker, http://www.newyorker.com/reporting/2013/05/27/130527fa_fact_packer (May 27, 2013); George Packer, A Reply From Silicon Valley, The New Yorker: Interesting Times, http://www.newyorker.com/online/blogs/georgepacker/2013/05/silicon-valley-taxes-andlibertarianism.html (May 26, 2013).

${ }^{24}$ In that vein, I sometimes consider the irony of the fact that Thorsten Veblen, author of The Theory of the Leisure Class, was a faculty member at Stanford and once lived in the neighborhood in Menlo Park where my family lived when I was born.

25 See Jeremy Paul, Why Young People Are Rejecting Law School, National Law Journal, http://www.nationallawjournal.com/id=1202627833122, Nov. 18, 2013.
} 


\section{Madison, Visions of the Future of (Legal) Education \\ Page 35 of 38 \\ March 20, 2014}

nobility of this argument, because the imagery and mythology draws on so much that is great about lawyers and the law through history.

Is there any evidence that it works to inspire teachers and students of the new generation? Or that it should? I object to techno-centrism; I object, too, to an approach that reminds me of the old American Express line: "Membership has its privileges." Like law-as-engineering, legal exceptionalism has its attractions and its place. There is a way to re-cast it, I think, in terms of service, and in that sense it's a great idea. But I don't want to rest a case on lawyers' status, implicit in the idea that they do not get the respect that they deserve because of all the amazing stuff that they do. I resist the notion that lawyers occupy some special status as of right and that what ails the profession and its law schools can be cured by better marketing. To borrow a different advertising slogan, one that John Houseman used to conclude old Smith Barney commercials, lawyers aren't entitled to that special status. They have to earn it.

The crucial gap that legal educators need to close is not a perception gap; what ails lawyers and law schools is not the messaging. The gap is that as teachers we do a lousy job, in general, of helping our students become the people that they want to become as lawyers, of helping them see who they might become if they do not have much of an idea themselves, and of helping them see how they can change the world and the lives of people within it using the knowledge, skills, and values that they've acquired and that make them who they are. That's the point of organizing education around the service theme. The marketing is important, and it doesn't take care of itself, but the work begins with substance and with values. It's a service business. New lawyers have to earn their roles, their stature, and when appropriate, their reward they have to be inspired, in order to earn it - and as law professors we need to ensure that making that happen is a central part of our identity and our purpose. Our value set, as it were. It's not only the values that define the law and its institutions that guide this processes. Our students' values have to be present and accounted for, and our own, as educators, as well.

It is certainly possible that many individual law professors do a wonderful job of this — inspiring students through the shared value of service — and that few of their colleagues know about it and/or that their work has not penetrated the dominant narratives that define what legal education "is." My strong sense, however, is that this role, to the extent that it exists in legal education, has been largely if implicitly ceded 


\section{Madison, Visions of the Future of (Legal) Education \\ Page 36 of 38 \\ March 20, 2014}

to clinical law faculty, and sometimes to adjunct or other contingent faculty and sometimes to legal writing faculty, and even in those settings the role often gets clouded by arguments about teachers' professional status and recognition and compensation. Across all faculties, a sense of shared values and purposes - helping to create the people that we want our graduates to be and that our graduates want to be, and helping them to create the change that they want to effect in society - needs to be restored to a central place across the entire institution, from the bottom up and from the top down.

\section{The End}

I asked at the outset whether there is anything to learn here by trying to begin again. I think that there is.

A close friend of mine, a practicing lawyer, received an award recently, recognizing him for substantial contributions to public service going back over 35 years. He stepped into first major, global leadership role when he was a senior in high school. That record, that life in service, is an extraordinary thing. Here is something that is less extraordinary, or at least that should be less extraordinary. In his acceptance speech my friend made a point not only of thanking a wide range of people who helped and influenced him but also of highlighting something that is directly relevant, I think, to the essence of my thinking about what I do and who I am as a law professor.

He said that he was blessed to have been shown when he was quite young how he could have an impact on other people and on the world around him.

I might reduce to a single proposition my thinking about what I do and who I am, what I wish to do, and what I wish my peers and colleagues would do - a single statement of values, a single statement that could inspire both us, and our students, our alumni, and the broader community - to the following proposition:

I want to show my students and teach my students how they can have an impact on other people and on the world around them. My job is to inspire my students so that they can inspire change - for the better, if possible - in others. For many years after I left law practice and started teaching law, I didn't think of myself 


\section{Madison, Visions of the Future of (Legal) Education \\ Page 37 of 38 \\ March 20, 2014}

and my students in that way. I do now. When I started writing the first part of what became this Essay, I did not anticipate that I would conclude with this point, or that what I would learn is about myself as much or even more than about my students or about law schools in general. Is there something to learn in this exercise, in the sense of its revealing something that I didn't previously appreciate? That's it.

Different people can, will, and should, if they wish, take such a high-level statement of purpose (the latter part of this Essay) and put it into practice (the first part of this Essay) in different ways. I offered my own suggestions about how to do that, in concrete terms, in a blog post that I excerpt below:

Breaking the mold requires something else - some other kind of motivation and some other kind of execution among individual teachers, who are not indifferent to tenure or tradition but are not ruled by them, even if their own law schools are not innovating substantially at the institutional level. Despite the many structural barriers to innovation and improvement in teaching, at almost every American law school there are pockets of innovation - disruptive teachers - who are doing different things with their students and for a variety of reasons. Many of those things fall under the umbrella heading, "experiential education," but the label may mislead. What these things have in common is that they are different, in some large and in some small ways, and the differences are in almost all cases, in my anecdotal experience, aimed at better alignment of law teaching and the experiences of lawyers in the contemporary legal profession. No one imagines giving up the core strengths and traditions of American legal education - the emphasis on rigorous analytic thinking, the injunction to think critically independently and to communicate effectively. Langdellian education and its derivatives are not, however, the only ways to get there.

My advice, then, is this: If you're a Dean: Find these teachers, support them, and publicly and privately celebrate them and build around them. If you're a teacher and you're curious about this stuff, talk to these people and learn from them. If you're a law student, enroll in their classes! If you're an alum, press the Dean of your school to bring these people forward and engage with you and your colleagues in the 


\section{Madison, Visions of the Future of (Legal) Education \\ Page 38 of 38 \\ March 20, 2014}

legal profession. Build externship and internship pipelines that lead from their teaching to work with you and ultimately to full-time employment with you or elsewhere. Help the Dean amass the resources needed to support and celebrate these teachers and their students - tangibly, out of your own pocket, and intangibly, with political support and advocacy among your peers and colleagues. Or all of the above.

None of those things is as easy as I may have made it appear. Deans do not want to play favorites, or to appear to play favorites. Law teachers, especially veterans, often believe that they have no need to learn from peers, let alone from more junior colleagues. Students avoid things (teachers, subjects, styles) that don't look and act like things that they have already encountered and mastered. And alumni think that law schools should simply be doing this as part of the ordinary course of things. Land mines and risks, known and unknown, abound. ${ }^{26}$

Inspiring students means not only "giving" students knowledge and other tools, but also inspiring them to find and develop those tools for themselves. Substantive legal knowledge, skills, and competencies may be taught in a lot of different arrangements. What is different in those arrangements should not obscure what I think should be shared. My own sense of the current stresses about legal education - economic stresses about its cost and the returns, cultural stresses about its value and importance - is that those stresses owe their origins in large part to the absence of a collective understanding about the values that bind us together. If law schools are too numerous today or overpriced today or both (or neither), those problems follow from the absence of a collective understanding about purpose. Those problems, while important, are not root causes. Choose my value; choose some other value. What really matters, as it were, isn't only the raw economics of the thing. What really matters is why we're doing what we're doing.

\footnotetext{
26 Legal Education and the End of the Beginning, The Faculty Lounge, http://www.thefacultylounge.org/2012/10/legal-education-and-the-end-of-the-beginning.html (Oct. 25, 2012).
} 